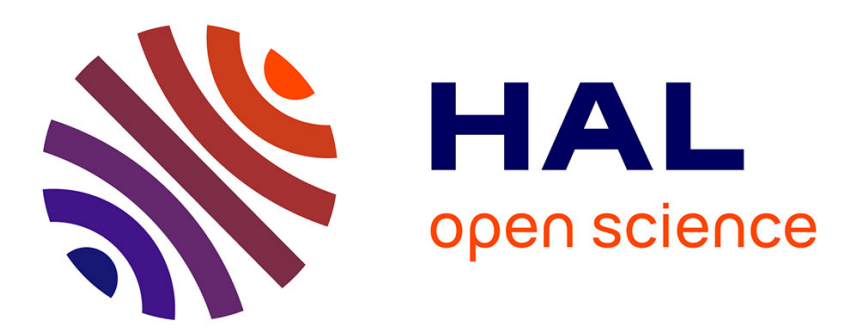

\title{
Throwing Activities Among Neolithic Populations from the Meuse River Basin (Belgium, 4500-2500 BC) with a Focus on Adolescents
}

Caroline Polet, Merlin Leunda Martiarena, Sébastien Villotte, Martine

Vercauteren

\section{To cite this version:}

Caroline Polet, Merlin Leunda Martiarena, Sébastien Villotte, Martine Vercauteren. Throwing Activities Among Neolithic Populations from the Meuse River Basin (Belgium, 4500-2500 BC) with a Focus on Adolescents. Childhood in the Past, 2019, Children at Work, 12 (2), pp.81-95. 10.1080/17585716.2019.1638555 . hal-02276330

\section{HAL Id: hal-02276330 \\ https://hal.science/hal-02276330}

Submitted on 22 Feb 2021

HAL is a multi-disciplinary open access archive for the deposit and dissemination of scientific research documents, whether they are published or not. The documents may come from teaching and research institutions in France or abroad, or from public or private research centers.
L'archive ouverte pluridisciplinaire HAL, est destinée au dépôt et à la diffusion de documents scientifiques de niveau recherche, publiés ou non, émanant des établissements d'enseignement et de recherche français ou étrangers, des laboratoires publics ou privés. 


\section{Throwing activities among Neolithic populations from the Meuse River Basin (Belgium, 4500-2500 BC) with a focus on adolescents}

Caroline Polet $^{\mathrm{a} *}$, Merlin Leunda Martiarena ${ }^{\mathrm{b}}$, Sébastien Villotte ${ }^{\mathrm{c}}$ and Martine Vercauteren ${ }^{\mathrm{b}}$

${ }^{a}$ Operational Directory Earth and History of Life, Royal Belgian Institute of Natural Sciences,

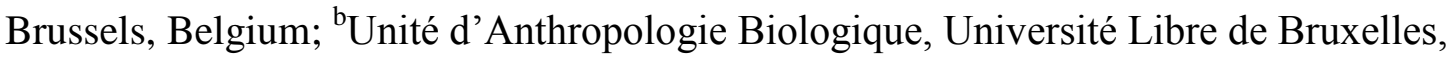
Brussels, Belgium; ${ }^{~}$ PACEA, Université de Bordeaux, Bordeaux, France

*Corresponding Author: caroline.polet@ naturalsciences.be

The anterior band of the medial collateral ligament (MCL) is an important stabilizer for valgus stress at the elbow. When practised intensively and repetitively, activities using overhead throwing motions can injure this ligament and its insertion (enthesis). If these activities occur when the epiphyses are not yet fully fused, traction forces can result in bony detachments in the area of the MCL insertion. On dry bones, such lesions can only be observed as scars in adults. The individuals in this study derive from commingled graves located in 16 caves from the Meuse River Basin that are radiocarbon dated to the Middle and Late Neolithic. We recorded the presence or absence of MCL lesions on 196 humeri and studied the relation between MCL lesions, siding, and robusticity. A total of $5.1 \%$ of the humeri displayed MCL lesions, which affected only the right robust humeri. Four main types of activities may explain the presence of this enthesopathy: hunting/fishing, warfare/conflict, games, and wood-cutting. Our results suggest the hypothesis of social division in throwing activities in the Meuse River Basin during the Neolithic. They also suggest that the throwing practice started from a young age, which invites us to re-examine the role of teenagers in prehistoric societies. 


\section{KEYWORDS}

Neolithic; throwing activity; avulsion fracture; adolescent; Belgium 


\section{Introduction}

When practised intensively (at high velocity and force) and repetitively, overhead throwing activities are very stressful to the elbow, and more particularly, to the anterior band of the medial collateral ligament (MCL) (Nakanishi et al. 1996; Miller, Adler, and Friedman 2004; Gregory and Nyland 2013). The MCL links the humerus with the ulna, arising from the medial humeral epicondyle and inserting on the ulnar coronoid process. It is the primary stabilizer against valgus stress at the elbow (Labott et al. 2018).

If throwing activities occur near the end of skeletal maturation, when the medial epicondyle (ME) is not yet fully fused (12-18 years of age), traction forces can result in bony detachments in the area of the MCL insertion (Figure 1). In individuals younger than 15years-old, these detachments can be complete and involve the entire medial epicondylar ossification centre. In older teens, they can be partial, leading to the avulsion of one or more bony fragments from the medial epicondylar apophysis (Klingele and Kocher 2002; Kijowski and Tuite 2010).

When the individual with an avulsion fracture reaches adulthood, the healed lesion takes the form of a bony outgrowth or lacunae depending on whether or not the avulsed fragment re-united with the condyle (Lewis 2017, 254-255). On dry archaeological bones, such lesions are mainly observed on adult humeri as scars from a traumatic event that occurred during adolescence (Villotte et al. 2010).

[Figure 1 near here]

Today, these ME injuries are common pathological findings in young baseball pitchers and are known as Little Leaguer's elbow (Klingele and Kocher 2002). They are also reported in javelin throwers (Miller 1960), but the incidence is lower, because Javelin competitions begin later - during high school in the United States (Gregory and Nyland 2013). 
The aim of this study was to look for the presence of avulsion fractures at the attachment site of the anterior band of the MCL during the Neolithic period in Belgium and thus demonstrate the occurrence of overhead throwing activities during adolescence in these prehistoric populations. We then try to answer the following question: who was practising these throwing activities, and based on archaeological data, in what context were these activities performed?

\section{Materials and methods}

More than 200 karstic caves located in the Meuse River Basin of Belgium have yielded human remains (Toussaint et al. 2001). The majority of these funerary sites date to the Middle and Late-Final Neolithic, as evidenced by over 100 available radiocarbon dates; only about a dozen sites belong to the Early Mesolithic, and some caves contained skeletons from the Protohistoric Period (Toussaint 2007). Many of these sites were excavated as early as the $19^{\text {th }}$ century (Table 1). Unfortunately, the skeletal remains are commingled and disarticulated. This is, of course, due to taphonomy, but it is also due to human manipulation of the remains, beginning in Prehistoric times (Toussaint et al. 2001). A great number of Neolithic burials include the remains of 5-15 individuals (Polet 2011) belonging to adults of both sexes and children (Toussaint et al. 2001).

\section{[Table 1 near here]}

For this study, we selected 196 left and right adult humeri (fully fused epiphyses) with preserved distal epiphyses from a collection housed at the Royal Belgian Institute of Natural Sciences. They derived from 16 cave burials and come from 9 sites in the Meuse Basin (Figure 2). Five caves are radiocarbon dated to the Middle Neolithic, nine to the Late-final Neolithic, and one (Grotte de la Cave in Maurenne) covers both periods (Table 1). One of the caves was not radiocarbon dated and is therefore indicated as 'supposed Neolithic'. The minimum number of individuals varies from 5 to 59 individuals (Table 1). 
[Figure 2 near here]

The presence or absence of changes at the humeral attachment site for the anterior band of the MCL (see fig. 5 in Villotte et al. 2010) was macroscopically recorded. We looked for two types of changes (see Villotte et al. 2016 for definitions and illustrations): a clearly distinct protrusion from the surface of the enthesis (Figure 3), or alternatively, a large surface discontinuity affecting the cortical bone and underlying trabecular bone (Figure 4; also see fig. 4 in Villotte et al. 2010).

\section{[Figures 3 and 4 near here]}

We studied the relation between the MCL lesions, siding, and robusticity, which was used instead of sex because skeleton individualization was not possible for these collective burials. Pelvic bones could not be associated with the humeri, and thus no reliable methods for a pelvis-based sex determination could be applied. Robusticity was evaluated using distal humerus measurements. From a series of six measurements (Table 2, Figure 5), two were selected because they could be taken on a maximum number of Neolithic humeri (Leunda Martiarena 2016, 40-41). These were the epicondylar breadth and the minimum trochlear depth. The epicondylar breadth (Measurement 4 in Martin 1928, 1010) is the maximum breadth between the most extreme aspects of the medial and lateral epicondyles of the humerus perpendicular to the axis of the humeral diaphysis. The minimum trochlear depth is the minimum anteroposterior dimension of the trochlea (Trinkaus 1983, 227). The humeri were classified as either gracile or robust based on a bivariate plot, where specimens with values below the median for both measurements were considered gracile, and those above were considered robust (Figure 6).

[Table 2 and Figure 5 near here] 
We applied the Fisher Exact test $(2 \times 2$ contingency table $)$ to test whether there was a difference in the lesion frequency between the Middle and Late Neolithic individuals. The Fisher-Freeman-Halton test $(2 \times 4$ contingency table $)$ was used to test whether there was a difference in frequency among the four groups of humeri: left and right gracile, and left and right robust.

[Figure 6 near here]

\section{Results}

Of the two types of lesions at the attachment site of the MCL anterior band, only the lacunar form was observed (Figure 4).

Table 3 shows the prevalence of MCL lesions at the 16 Neolithic burial sites. From a total of 196 humeri, 10 (5.1\%) displayed this kind of lesion, affecting 10.3\% (7/68) of the Late Neolithic individuals and 7.7\% (1/13) of the Middle Neolithic individuals (in the Grotte de la Cave in Maurenne dated to the Middle and Late Neolithic, $12.5 \%$ [2/16] of the individuals were affected). The probability derived from the Fisher Exact test (1.000) used to compare these two groups was greater than $5 \%$, and thus we cannot reject the null hypothesis (the distribution of the MCL lesions is independent of the chronological groups). We conclude that the frequency of fracture avulsions does not vary among the Late and Middle Neolithic groups.

\section{[Table 3 near here]}

The selection of robust and gracile individuals unfortunately resulted in the 'loss' of 91 individuals (specimens where either both measurements could not be taken or those where both measurements were not above or below the median values). The discussion will thus mainly concern the 105 remaining humeri. 
The MCL lesion only affected the right robust bones (33.3\% [7/21]; Table 4). None of the left humeri (gracile and robust) or right gracile humeri showed lesions. The probability determined from the Fisher-Freeman-Halton test (0.0000749) used to compare these four groups was less than 5\%, meaning we should reject the null hypothesis (the distribution of the MCL lesions is independent of the humeri groups). We conclude that the frequency of fracture avulsions varies among the four categories of humeri.

[Table 4 near here]

\section{Discussion}

Fracture avulsion scars at the insertion of the anterior band of the MCL on nine Neolithic individuals from the Meuse Basin indicate that severe valgus stress occurred at their elbows. No significant difference in the prevalence of lesions was observed between the Middle and the Late Neolithic individuals, indicating that throwing activities were performed during both periods.

Only the right humeri were affected by the avulsion fractures. This result was expected, as the valgus extension of the elbow is usually only reached by the dominant upper limb, given its dynamic and complex properties. Today, the right arm is dominant for about $90 \%$ of the population (Scharoun and Bryden 2014), which and it was also likely the case in prehistoric times based on studies on tool processing (Steele and Uomini 2005) and handling (Phillipson 1997), cut mark direction (Bromage and Boyde 1984; Pickering and Hensley-Marschand 2008), humeral diaphysis asymmetry (Trinkaus, Churchill, and Ruff 1994; Sparacello et al. 2017), entheseal changes (Villotte and Knüsel 2014), directional skew in dental wear (Bermùdez de Castro, Bromage, and Fernàndez Jalvo 1988; Frayer et al. 2012), cave art (Coren and Porac 1977), and endocast asymmetries (Holloway 2008; Poza-Rey, Lozano, and Arsuaga 2017). 
In our Neolithic sample, only robust humeri were affected by the avulsion fractures. Can we go one step further and state that some specific activities that produce severe valgus stress concerned only male individuals? Several studies have shown a marked sexual dimorphism also exists at the humerus level that allows reliable sex determination when it is not possible to sex either the pelvis or skull (e.g. İşcan et al. 1998; Steyn and İşcan 1999; Kranioti and Michalodimitrakis 2009). In addition, the application of our graphic method based on the median values of two distal humerus measurements to a modern identified collection (known sex) shows good sexual discrimination (Leunda Martiarena 2016, 40-41). Finally, the fact that we used parameters (medians) calculated from our data avoids the bias of transposing methods created on a given population to another with different body proportions (Ruff 2002). All of the above indicates that humerus robusticity can be a good sex indicator in our Neolithic sample. Thus, most of the gracile humeri probably belonged to females, and most of the robust humeri to males. However, it is not impossible that some robust humeri belong to females and vice versa, and thus some avulsions actually occurred in females.

If we look at current sport medicine data, the lesions in our Neolithic sample were likely due to activities that involve a throwing motion (Kijowski and Tuite 2010). These lesions typically result from repetitive stress due to overuse, but they can also be secondary to acute localized trauma (Gore et al. 1980; Gregory and Nyland 2013). Our results are similar to those of previous studies that, on the basis of changes at the ME (including the attachment site of the MCL), have demonstrated that prehistoric males were engaged in activities inferring a throwing motion (Dutour 1986; Villotte and Knüsel 2014; Villotte et al. 2010).

As the lesions observed on the ME in our sample are scars from avulsions that occurred in adolescents whose skeletons had not fully matured, they indicate these activities began before biological adulthood. This is a major outcome, because adolescent activities in prehistoric periods are poorly documented. Information on their place in prehistoric society has been 
inferred by funerary anthropology by associating the study of skeletal remains with patterns in grave goods and burial rites (Thomas, Chambon, and Murail 2011; Leroy 2015). However, this provides little information on their actual activities during life. Based on the study of artefacts, child participation in craft activities, including stone-tool production, ceramic manufacture, and weaving, has already been demonstrated in prehistoric populations (Baxter 2008). Still, only a few of these studies were able to distinguish different age categories in non-adults (including adolescents) using the types of errors related to cognitive developmental stages (Crown 1999; Bagwell 2002). Two anthropological studies have nevertheless demonstrated a strenuous lifestyle (in the broader sense) during adolescence in prehistoric populations: Lovejoy and Heiple (1981), based on fracture rates in a Late Woodland sample from Ohio in the United States; and Mays et al. (2018), looking at spondylosis (a fatigue fracture of the neural arch, usually occurring in late adolescence or early adulthood in archaeological groups) in one Middle Neolithic male individual from Stonehenge

Based on archaeological and ethnographical data, we tried to reconstruct the activities which caused the ME lesions. They could belong to four main categories: hunting/fishing, warfare/conflict, games, and wood-cutting.

Faunal remains analyses from Neolithic sites in Belgium show that breeding was the most important source of animal protein (Cauwe, Vander Linden, and Vanmonfort 2001). However, hunting and fishing were still performed, as demonstrated by the faunal remains at some Neolithic sites (e.g. De Ceunynck, Van der Plaetsen, and Vanmoerkerke 1985; Léotard, Straus, and Otte 1999) and by stable isotope analyses (Bocherens, Polet, and Toussaint 2007). The use of the bow, widely attested for the Neolithic period in Europe, does not seem to be stressful for the ME (Villotte et al. 2010). However, its frequent adoption does not exclude 
the use of more simple overhead throwing weapons such as the sling, harpoon, killing stick, or even the boomerang (Ramseyer 1988, 2000; Thomas 2000).

Interpersonal violence, which has been detected in the Middle Pleistocene (Sala et al. 2015), increased during the development of the first agro-pastoral societies in the Neolithic (Keeley 1997; Guilaine and Zammit 2001; Beyneix 2001; Maxwell Heath 2017). Although the traumatic lesions observed on the skeletons from Belgian Neolithic sites generally attest to injuries by arrows (Cauwe 1999; Polet et al. 1996; Joppart, Polet, and Warmenbol 2017), it is easy to imagine that overhead throwing weapons, such as the spear in Denmark (Bennike 1985, 110-112), could also have been used.

Games and sports are seldom considered as an interpretative model in archaeology due to the belief that they were insignificant in prehistory, as well as the paucity of uncovered artefacts (Fox 1977; Sansone 1988, 5). Nevertheless, many scholars are convinced that play has been a part of human society since prehistoric times given its ubiquity among primates and the free time at the disposal of prehistoric people (Blanchard and Taylor Cheska 1985, 96-97). Throwing games could have been practiced by all the male members of the Neolithic society in the Meuse River Basin or only by adolescents as training for the accurate and coordinated throwing of weapons for killing prey (or enemies?) (Reid 2001, 3).

It should also be noted that the use of the axe and adze require very similar movements of the upper limb as those made during overhead throwing and could also lead to ME lesions (Villotte and Knüsel 2014). It can be assumed that their use, observed since the Mesolithic (Verhart 2012), was very frequent during the Neolithic period, when intense deforestation occurred to clear land for agriculture (Roberts et al. 2018).

The participation of adolescents in any of the above activities should be considered. Parallels can, for example, be drawn with present-day traditional societies such as contemporary hunter-gatherers, where teenagers learn various complex skills such as big 
game hunting during apprenticeships and initiation rites (MacDonald 2007; Hewlett 2016; Lew-Levy et al. 2017).

\section{Conclusions}

Lesions at the attachment site of the anterior band of the MCL were present during the Neolithic period in the Meuse Basin of Belgium. We have demonstrated that activities involving a throwing motion began in adolescence, suggesting we re-examine the role of teenagers in these prehistoric societies. The fact that it is only the more robust individuals that were affected leads to the hypothesis that it was probably the male individuals that were involved in throwing activities. This, in turn, suggests the hypothesis of a form of social/gender division in throwing activities in the Meuse River Basin during the Neolithic.

Based on archaeological data, four main types of activities can be proposed to explain the presence of this enthesopathy related to throwing activities: hunting/fishing, warfare/conflict, games, and wood-cutting. However, it is difficult based on our present knowledge and the available data to determine which is the more probable.

\section{Acknowledgements}

This work was performed with the support of the Wallonia-Brussels International and the Scientific Research Fund, the French Ministry of Foreign and European Affairs, and the Ministry of Higher Education and Research in the framework of the Hubert Curien Partnerships (Biologie, pathologie et comportements des derniers chasseurs-cueilleurs d'Europe occidentale, SCO/AD/FR - SOR/2015/223020). We would like to express our sincere thanks to Quentin Goffette (RBINS) for helpful comments and discussions on Neolithic subsistence, fishing, and hunting. We are particularly indebted to Katrien Van de Vijver (RBINS) for providing information on the reconstitution of adolescent activities from 
the skeleton. Tara Chapman (RBINS) is gratefully acknowledged for proof-reading and language revision.

declaration of interest statement: none 


\section{References}

Bagwell, E. A., 2002. Ceramic form and skill: attempting to identify child producers at Pecos Pueblo, New Mexico. In Children in the Prehistoric Puebloan Southwest, edited by Kamp, K., 90-107. Salt Lake City: University of Utah Press.

Baxter, J. E., 2008. “The archaeology of childhood.” Annual Review of Anthropology 37: doi:159-175. 10.1146/annurev.anthro.37.081407.085129.

Bennike, P., 1985. Palaeopathology of Danish skeletons. Copenhagen: Akademisk Forlag.

Bermùdez de Castro, J.M., T.G. Bromage, and Y. Fernàndez Jalvo. 1988. "Buccal striations on fossil human anterior teeth: evidence of handedness in the middle and early Upper Pleistocene.” Journal of Human Evolution 17: 403-412. doi:10.1016/0047-2484(88)90029-

2.

Beyneix, A. 2001. "Aux origines de la guerre : actes de violence et massacres dans le Néolithique européen." Revue des Études Anciennes 103 (3-4): 329-342.

Blanchard, K., and A. Taylor Cheska. 1985. The anthropology of sport: An introduction. South Hadley (USA): Bergin \& Garvey Publishers.

Bocherens, H., C. Polet, and M. Toussaint. 2007. "Palaeodiet of Mesolithic and Neolithic populations of Meuse Basin (Belgium): evidence from stable isotopes." Journal of Archaeological Science 34 (1): 10-27. doi: 10.1016/j.jas.2006.03.009.

Bromage, T.G., and A. Boyde. 1984. "Microscopic criteria for the determination of directionality of cutmarks on bone." American Journal of Physical Anthropology 65: 359366. doi: 10.1002/ajpa.1330650404.

Cauwe, N. 1993. “Origine mésolithique des sépultures collectives en grotte de Belgique, à propos d'une fouille récente à Freyr (Dinant)" In Actes de la première Journée d'Archéologie namuroise, 27 février 1993 edited by Plumier, J., and M.-H. Corbiau, 41-49. 
Namur (Belgium): Ministère de la Région Wallonne DGATL et Facultés universitaires Notre-Dame de la Paix.

Cauwe, N. 1999. "La grotte Bibiche à Anseremme (Dinant). Une sépulture collective du Néolithique récent." Anthropologie et Préhistoire 110: 61-90.

Cauwe, N., M. Vander Linden, and B. Vanmontfort. 2001. "The Middle and Late Neolithic." Anthropologica et Praehistorica 112: 77-89.

Charles, R. 1998. Late Magdalenian chronology and faunal exploitation in the North-Westem Ardennes. BAR International Series, 737.

Coren S., and C. Porac. 1977. "Fifty centuries of right-handedness: the historical record." Science 198 (4317): 631-632. doi: 10.1126/science.335510.

Crown, P. 1999. Socialization in American southwest pottery decoration. In Pottery and people: A dynamic interaction, edited by Skibo, J., and G. Feinman, 25-43. Salt Lake City: University of Utah Press.

De Paepe, M., and C. Polet. 2007. " "Numerous and tall": a revision of the Late Neolithic human remains found in a collective burial site at Sclaigneaux (Prov. Namur), Belgium.” Notae Praehistoricae 27: 163-168.

De Ceunynck, R., P. Van der Plaetsen, and J. Vanmoerkerke. 1985. "NeolithicumBronstijdvondsten aan de Donk te Oudenaarde. " Archaeologia Belgica 1 : 67-79.

Dumbruch, I. 2007. "Le Site de l'Abri-sous-Roche du Bois-Madame à Arbre (Province de Namur, Belgique).”Archaeologia Mosellana 7: 609-612.

Dutour, O. 1986. Enthesopathies (lesions of muscular insertions) as indicators of the activities of Neolithic Saharan populations. American Journal of Physical Anthropology 71 (2): 221-224. doi: 10.1002/ajpa.1330710209. 
Fox, S.J. 1977. "A paleoanthropological approach to recreation and sporting behaviors.” In Studies in the anthropology of play edited by Tindall, B.A., and P. Stevens, 65-70. West Point (N.Y.): Leisure Press.

Frayer, D.W., M. Lozano, J.M. Bermúdez de Castro, E. Carbonell, J.L. Arsuaga, J. Radovčić, I. Fiore, and L. Bondioli. 2012. "More than 500,000 years of right-handedness in Europe." Laterality 17, 51-69.

Gilot, E. 1985. “Le squelette de Salet dans la chronologie ${ }^{14}$ C.” Helinium 25: 190-193.

Gilot, E. 1986. “Abri Masson à Sprimont : datation ${ }^{14}$ C.” In L'ossuaire néolithique de l'abri Masson (Sprimont) edited by Dewez, M., E. Gilot, and M. Toussaint, 43-44. Liège: Société wallonne de Palethnologie, mémoire 6.

Gore, R.M., L.F. Rogers, J. Bowerman, J. Suker, and C.L. Compere. 1980. "Osseous manifestations of elbow stress associated with sports activities." American Journal of Roentgenology 134 (5): 971-917. doi: 10.2214/ajr.134.5.971.

Gregory B., and J. Nyland. 2013. "Medial elbow injury in young throwing athletes." Muscles, Ligaments and Tendons Journal 3(2): 91-100. doi: 10.11138/mltj/2013.3.2.91

Guilaine, J., and J. Zammit. 2001. Le sentier de la guerre. Visages de la violence préhistorique. Paris: Éditions du Seuil.

Hewlett, B.S. 2016. "Social Learning and Innovation in Hunter-Gatherers." In Social Learning and Innovation in Contemporary Hunter-Gatherers. Evolutionary and Ethnographic Perspectives edited by Terashima, H., and B.S. Hewlett, 1-15. Tokyo: Springer Japan.

Holloway, R.L. 2008. "The human brain evolving: A personal retrospective." In The human brain evolving: Paleoneurological Studies in Honor of Ralph L. Holloway edited by Broadfield D., M. Yuan, K. D. Schick, and N. Toth, 1-14. Gosport: Stone Age Institute Press. 
İşcan, M.Y., S.R. Loth, C.A. King, D. Shihai, and M. Yoshino. 1998. "Sexual dimorphism in the humerus: A comparative analysis of Chinese, Japanese and Thais." Forensic Science International 98 (1): 17-29. doi: 10.1016/S0379-0738(98)00119-4

Joppart, A., C. Polet, and E. Warmenbol. 2017. "Etude anthropologique et taphonomique de la sépulture néolithique de Martouzin-Neuville (comm. de Beauraing, BE)." Notae Praehistoricae 37: 125-143.

Keeley, L.H. 1997. War Before Civilization: The Myth of the Peaceful Savage. Oxford: Oxford University Press.

Kijowski, R., and M.J. Tuite. 2010. "Pediatric throwing injuries of the elbow." Seminars in Musculoskeletal Radiology 14 (4): 419-429. doi: 10.1055 / s-0030-1263257.

Klingele, K.E., and M.S. Kocher. 2002. "Little league elbow: valgus overload injury in the paediatric athlete." Sports Medicine 32(15): 1005-115. doi: 10.2165/00007256-20023215000004.

Kranioti, E.F., and M. Michalodimitrakis. 2009. "Sexual dimorphism of the humerus in contemporary Cretans - A population-specific study and a review of the literature." Journal of Forensic Sciences 54 (5): 996-1000. doi: 10.1111/j.1556-4029.2009.01103.x.

Labott, J.R., W.R. Aibinder, J.S. Dines, and C.L. Camp. 2018. "Understanding the medial ulnar collateral ligament of the elbow: Review of native ligament anatomy and function." World Journal of Orthopedics 9 (6): 78-84. doi: 10.5312/wjo.v9.i6.78.

Leguebe, A., and R. Orban, 1984. "Paléontologie humaine." In Peuples chasseurs de la Belgique préhistorique dans leur cadre naturel edited by Cahen, D. and P. Haesaerts, 87100. Bruxelles : Patrimoine de l'Institut royal des Sciences naturelles de Belgique.

Léotard, J.M., L.G. Straus, and M. Otte, ed. 1999. L'abri du Pape. Bivouacs, enterrements et cachettes sur la Haute Meuse belge : du Mésolithique au Bas Empire Romain. Liège: ERAUL 88. 
Le Roy, M. 2015. "Les enfants au Néolithique : du contexte funéraire à l'interprétation socioculturelle en France de 5700 à 2100 avant J.-C. ” PhD diss., University of Bordeaux.

Leunda Martiarena, M. 2016. “Analyse d'un marqueur d'activité dans une population humaine préhistorique. Le lancer des individus néolithiques du Bassin mosan.” Master diss., Université Libre de Bruxelles.

Lew-Levy S., R. Reckin, N. Lavi, J. Cristóbal-Azkarate and K. Ellis-Davies. 2017. "How Do Hunter-Gatherer Children Learn Subsistence Skills? A Meta-Ethnographic Review." Human Nature 28 (4): 367-394. doi: 10.1007/s12110-017-9302-2.

Lewis, M. 2017. Paleopathology of children: identification of pathological conditions in the human skeletal remains of non-adults, London: Academic Press.

Lovejoy, C.O., and K.G. Heiple. 1981. "The analysis of fractures in skeletal populations with an example from the Libben site, Ottowa County, Ohio." American Journal of Physical Anthropology 55 (4): 529-541. doi: 10.1002/ajpa.1330550414.

Martin, R. 1928. Lehrbuch der Anthropologie in Systematischer Darstellung mit Besonderer Berücksichtigung der Anthropologischen Methoden für Studierende, Ärtze und Forschungsreisende. Zweiter Band: Kraniologie, Osteologie. 2nd ed., Jena (Germany): Gustav Fischer.

Maxwell Heath, J. 2017. Warfare in Neolithic Europe: An archaeological and anthropological analysis. Barnsley (UK): Pen \& Sword Books Ltd.

Mays, S., D. Roberts, P. Marshall, A.W.G. Pike, V. van Heekeren, C. Bronk Ramsey, E. Dunbare, P. Reimer, B.Linscott, A. Radini, A.Lowe, A. Dowl, C.Speller, J. Vallender, and J. Bedford. 2018. "Lives before and after Stonehenge: An osteobiographical study of four prehistoric burials recently excavated from the Stonehenge World Heritage Site." Journal of Archaeological Science: Reports 20: 692-710. doi: 10.1016/j.jasrep.2018.06.008. 
MacDonald, K. 2007. "Cross-cultural comparison of learning in human hunting: Implications for life history evolution." Human Nature 18 (4): 386-402. doi: 10.1007/s12110-007-90198.

Miller, J.E. 1960. "Javelin thrower's elbow.” Journal of Bone and Joint Surgery 42B: 788792.

Miller, T.T., R.S. Adler, and L. Friedman. 2004. "Sonography of injury of the ulnar collateral ligament of the elbow-initial experience." Skeletal Radiology 33 (7): 386-91. doi: $10.1007 / \mathrm{s} 00256-004-0788-4$

Nakanishi, K., T. Masatomi, T. Ochi, T. Ishida, S. Hori, J. Ikezoe, and H. Nakamura. 1996. "MR arthrography of elbow: evaluation of the ulnar collateral ligament of elbow." Skeletal Radiology 25 (7): 629-634. doi: 10.1007/s002560050.

Orban, R., C. Polet, P. Semal, and A. Leguebe. 2000. "La stature des Néolithiques mosans." Bulletin de l'Institut royal des Sciences naturelles de Belgique, Sciences de la Terre 70 : 207-222.

Phillipson, L. 1997. "Edge modification as an indicator of function and handedness of Acheulian handaxes from Kariandusi, Kenya." Lithic Technology 22: 171-183. doi: $10.1080 / 01977261.1997 .11754541$

Pickering, T.R., and B. Hensley-Marschand. 2008. "Cutmarks and hominid handedness." Journal of Archaeological Science 35: 310-315. doi: 10.1016/j.jas.2007.03.012.

Polet, C. 2011. "Les squelettes néolithiques découverts dans les grottes du bassin mosan.” In 5200-2000 av. J.-C. Premiers agriculteurs en Belgique, edited by Cauwe, N., A. Hauzeur, I., Jadin, C. Polet, and B. Vanmontfort, 85-94. Treignes (Belgium): Éditions du Cedarc.

Polet, C., O. Dutour , R. Orban , I. Jadin, and S. Louryan. 1996. “A healed wound caused by a flint arrowhead in a Neolithic human hip bone of the "Trou Rosette" (Furfooz, Belgium)." 
International Journal of Osteoarchaeology 6: 414-420. doi: 10.1002/(SICI)10991212(199609)6:4<414::AID-OA284>3.0.CO;2-3.

Poza-Rey, E.M., M. Lozano, J.L. Arsuaga. 2017. "Brain asymmetries and handedness in the specimens from the Sima de los Huesos site (Atapuerca, Spain).” Quaternary International 433 A: 32-44. doi: 10.1016/j.quaint.2015.10.004.

Ramseyer, D. 1988. “Les harpons néolithiques d'Europe occidentale." Bulletin de la Société préhistorique française 85 (4) : 115-122.

Ramseyer, D. 2000. "Les armes de chasse néolithiques des stations lacustres et palustres suisses." Anthropologie et Préhistoire 111: 130-142.

Reid, S.E., 2001. "The psychology of play and games." In Game play: therapeutic use of childhood games edited by Schaefer, C.E., and S.E. Reid. $2^{\text {nd }}$ ed., 1-36. New York: John Wiley \& Sons.

Roberts, N., R.M. Fyfe, J. Woodbridge, M.J. Gaillard, B.A.S. Davis, J.O. Kaplan, L. Marquer, F. Mazier, A.B. Nielsen, S. Sugita, A.K. Trondman, and M. Leydet. 2018. "Europe's lost forests: a pollen-based synthesis for the last 11,000 years." Nature Scientific Reports 8(1): article 716. doi: 10.1038/s41598-017-18646-7.

Ruff, C.F. 2002. "Variation in human body size and shape." Annual Review of Anthropology 31: 211-232.

Sala, N., J.L. Arsuaga, A. Pantoja-Pérez, A. Pablos, I. Martínez, R.M. Quam, A. GómezOlivencia, J.M. Bermúdez de Castro, and E. Carbonell. 2015. "Lethal interpersonal violence in the Middle Pleistocene. " PLoS One 10 (5) article e0126589: 1-12.

Sansone, D. 1988. Greek athletics and the genesis of sport. Berkeley: University of California. 
Scharoun, S.M., and P.J. Bryden. 2014. "Hand preference, performance abilities, and hand selection in children." Frontiers in Psychology 5, article 82: 1-15. doi: 10.3389/fpsyg.2014.00082.

Sparacello, V.S., S. Villotte, L.L Shackelford, and E.Trinkaus. 2017. "Patterns of humeral asymmetry among Late Pleistocene humans." Comptes Rendus - Palevol 16 (5-6):, 680689. doi: 10.1016/j.crpv.2016.09.001

Steele, J., and N. Uomini. 2005. "Humans, tools and handedness." In knapping: the necessary conditions for a unique hominin behaviour edited by Roux, V., and B. Bril, 217-239. Cambridge (UK): McDonald Institute for Archaelogical Research.

Steyn, M., and M.Y. İşcan. 1999. "Osteometric variation in the humerus: sexual dimorphism in South Africans." Forensic science international 106 (2): 77-85. doi: 10.1016/S03790738(99)00141-3.

Thomas, A., P. Chambon, and P. Murail. 2011. "Unpacking burial and rank: the role of children in the first monumental cemeteries of Western Europe (4600-4300 BC).” Antiquity 85 (329): 772-786.

Thomas, J. 2000. "Les boomerangs aux temps anciens." Anthropologie et Préhistoire 111: 143-151.

Toussaint, M., R. Orban, C. Polet, P. Semal, H. Bocherens, P. Masy, and C. Garcia-Martin. 2001. “Apports récents sur l'anthropologie des Mésolithiques et des Néolithiques mosans.” Anthropologica et Prehistorica 112: 91-105.

Toussaint, M. 2007. "Les sépultures néolithiques du bassin mosan wallon et leurs relations avec les bassins de la Seine et du Rhin.” Archaeologia Mosellana 7: 507-549.

Trinkaus, E. 1983. The Shanidar Neandertals. New York: Academic Press. 
Trinkaus, E., S.E. Churchill, and C.B. Ruff. 1994. "Postcranial robusticity in Homo. II. humeral bilateral asymmetry and bone plasticity." American Journal of Physical Anthropology 93: 1-34. doi: 10.1002/ajpa.1330930102.

Verhart, L. 2012; “Contact in stone: adzes, Keile and Spitzhauen in the Lower Rhine Basin. Neolithic stone tools and the transition from Mesolithic to Neolithic in Belgium and the Netherlands, 5300-4000 cal BC" Journal of Archaeology in the Low Countries 4 (1): 5-35.

Villotte, S., S.E. Churchill, O.J. Dutour, and D. Henry-Gambier. 2010 "Subsistence activities and the sexual division of labor in the European Upper Paleolithic and Mesolithic: Evidence from upper limb enthesopathies." Journal of Human Evolution 59 (1): 35-43. doi: 10.1016/j.jhevol.2010.02.001.

Villotte, S., and C.J. Knüsel, 2014. “"I sing of arms and of a man...”: medial epicondylosis and the sexual division of labour in prehistoric Europe." Journal of Archaeological Science. 43: 168-174. doi: 10.1016/j.jas.2013.12.009.

Villotte, S., S. Assis, F. Alves Cardoso, C.Y. Henderson, V. Mariotti, M. Milella, D. PanyKucera, N. Speith, C.A. Wilczak, and R. Jurmain. 2016. "In Search of Consensus: Terminology for Entheseal Changes (EC)”. International Journal of Paleopathology 13: 4955. https://doi.org/10.1016/j.ijpp.2016.01.003. 


\section{Tables}

\begin{tabular}{|c|c|c|c|c|c|c|c|c|c|}
\hline Locality & Name of the site & excavation & Date $^{14 \mathrm{C}} \mathrm{BP}$ & Date Ref. & Date BC 2 o & $\begin{array}{l}\text { Itural } \\
\text { cibution }\end{array}$ & Ref. & MNI & $\mathbf{N}$ \\
\hline Sclaigneaux & Grotte de Sclaigneaux & 1872 & $4155 \pm 35$ & GrA-32975 & $2880-2620$ & $\mathrm{LN}$ & De Paepe and Polet 2007 & 58 & 47 \\
\hline \multirow[t]{2}{*}{ Anseremme } & Abri du Grogneau & $1946-47$ & $4945 \pm 55$ & OxA-9089 & $3780-3660$ & $\mathrm{MN}$ & Orban et al. 2000 & $?$ & 2 \\
\hline & Abri des Autours & 1992 & $5300 \pm 55$ & OxA-5387 & $4320-3980$ & $\mathrm{MN}$ & Cauwe 1993 & 9 & 1 \\
\hline \multirow[t]{6}{*}{ Hastière } & Caverne B & 1869-1879 & $5180 \pm 45$ & OxA-9021 & $4160-3930$ & $\mathrm{MN}$ & Orban et al. 2000 & 14 & 5 \\
\hline & Caverne L & $1869-1879$ & $5070 \pm 60$ & OxA-9088 & $3980-3710$ & $\mathrm{MN}$ & Orban et al. 2000 & 5 & 6 \\
\hline & Caverne M & $1873 ?$ & $4345 \pm 60$ & OxA-6852 & $3320-2870$ & $\mathrm{LN}$ & Orban et al. 2000 & 44 & 17 \\
\hline & Petite Caverne & $1869-1879$ & $4300 \pm 50$ & OxA-6852 & $3090-2700$ & $\mathrm{LN}$ & Orban et al. 2000 & 20 & 1 \\
\hline & Le Cimetière & $1869-1879$ & $4280 \pm 50$ & OxA-6851 & $3030-2690$ & $\mathrm{LN}$ & Orban et al. 2000 & 19 & 4 \\
\hline & Caverne $\mathrm{C}$ & $1869-1879$ & $4220 \pm 45$ & OxA-6853 & $2910-2620$ & $\mathrm{LN}$ & Orban et al. 2000 & $?$ & 4 \\
\hline \multirow[t]{4}{*}{ Maurenne } & \multirow[t]{4}{*}{ Grotte de la Cave } & \multirow[t]{4}{*}{ 1869-1879 } & $4635 \pm 45$ & OxA-9025 & $3630-3130$ & $\mathrm{MN}$ & Orban et al. 2000 & \multirow[t]{4}{*}{59} & \multirow[t]{4}{*}{34} \\
\hline & & & $4360 \pm 45$ & OxA-6854 & $2880-2590$ & $\mathrm{LN}$ & Orban et al. 2000 & & \\
\hline & & & $3830 \pm 30$ & Lv-1482 & $2600-1950$ & $\mathrm{LN}$ & Gilot 1985 & & \\
\hline & & & $3830 \pm 70$ & Lv-1483 & $2470-2030$ & $\mathrm{LN}$ & Gilot 1985 & & \\
\hline \multirow[t]{3}{*}{ Furfooz } & \multirow[t]{2}{*}{ Trou du Frontal } & \multirow[t]{2}{*}{$1864-65$} & $4430 \pm 80$ & OxA- 8828 & $3350-2920$ & $\mathrm{LN}$ & Charles 1998 & \multirow[t]{2}{*}{21} & \multirow[t]{2}{*}{8} \\
\hline & & & $4430 \pm 30$ & GrN-10179 & $3330-2920$ & $\mathrm{LN}$ & Leguebe and Orban 1984 & & \\
\hline & Trou Rosette & $1864-65$ & $4165 \pm 70$ & OxA-5041 & $3900-2500$ & $\mathrm{MN}$ & Polet et al. 1996 & 14 & 7 \\
\hline \multirow[t]{2}{*}{ Brunot } & \multirow[t]{2}{*}{ Bois Madame } & \multirow[t]{2}{*}{1938} & $4110 \pm 110$ & Lv-265 & $2950-2300$ & $\mathrm{LN}$ & \multirow[t]{2}{*}{ Dumbruch 2007} & \multirow[t]{2}{*}{57} & \multirow[t]{2}{*}{17} \\
\hline & & & $4090 \pm 110$ & Lv-264 & $2950-2300$ & $\mathrm{LN}$ & & & \\
\hline \multirow[t]{6}{*}{ Beauraing } & \multirow[t]{6}{*}{ Martouzin-Neuville } & \multirow[t]{6}{*}{1977} & $4230 \pm 40$ & KIA-48286 & $2920-2670$ & $\mathrm{LN}$ & \multirow{4}{*}{\begin{tabular}{|l|} 
Joppart, Polet and \\
Warmenbol 2017
\end{tabular}} & \multirow[t]{6}{*}{34} & \multirow[t]{6}{*}{3} \\
\hline & & & $4140 \pm 40$ & KIA-48293 & $2880-2580$ & $\mathrm{LN}$ & & & \\
\hline & & & $4135 \pm 35$ & KIA-48292 & $2880-2580$ & $\mathrm{LN}$ & & & \\
\hline & & & $3760 \pm 35$ & KIA-48285 & $2290-2040$ & $\mathrm{LN}$ & & & \\
\hline & & & $4070 \pm 100$ & Fra-98 & $2870-2480$ & $\mathrm{LN}$ & Gilot 1986 & & \\
\hline & & & $3790 \pm 90$ & Lv-1243 & $2500-1950$ & $\mathrm{LN}$ & Gilot 1986 & & \\
\hline Bouvignes & Trou Madame & $1869-1879$ & \multicolumn{4}{|c|}{ Supposed Neolithic } & & $?$ & 1 \\
\hline \multirow[t]{2}{*}{ Humain } & \multirow{2}{*}{$\begin{array}{l}\text { Abri sous-roche } \\
\text { d'Humain }\end{array}$} & \multirow[t]{2}{*}{1962} & $4150 \pm 35$ & KIA-48288 & $2880-2620$ & $\mathrm{LN}$ & \multirow[t]{2}{*}{ Polet et al. 2014} & \multirow[t]{2}{*}{40} & 32 \\
\hline & & & $4085 \pm 45$ & KIA-48289 & $2780-2480$ & $\mathrm{LN}$ & & & \\
\hline
\end{tabular}

Table 1. General information on the 16 burial sites from which the Mosan human material originates: locality, name of the site, excavation date, radiocarbon dating, cultural attribution, bibliographic references, minimum number of individuals (MNI; estimated on all the available adult and non-adult human remains), and the number of left and right humeri selected for this study. MN, Middle Neolithic; LN, Late Neolithic. 


\begin{tabular}{|l|l|l|l|}
\hline Name & Reference & No. & Definition \\
\hline epicondylar breadth & $\begin{array}{l}\text { Martin } \\
(1928,1010)\end{array}$ & 4 & $\begin{array}{l}\text { maximum distance between the most extreme aspects of the } \\
\text { medial and the lateral epicondyles, perpendicular to the axis of } \\
\text { the diaphysis }\end{array}$ \\
\hline $\begin{array}{l}\text { distal articular } \\
\text { breadth }\end{array}$ & $\begin{array}{l}\text { Martin } \\
(1928,1012)\end{array}$ & $12 . \mathrm{a}$ & $\begin{array}{l}\text { distance between the most medial point on the trochlea to the } \\
\text { most lateral point on the capitellum. }\end{array}$ \\
\hline $\begin{array}{l}\text { olecranon fossa } \\
\text { breadth }\end{array}$ & $\begin{array}{l}\text { Martin } \\
(1928,1012)\end{array}$ & 14 & $\begin{array}{l}\text { distance between the most medial point and the most lateral } \\
\text { point on margin the of the olecranon fossa }\end{array}$ \\
\hline $\begin{array}{l}\text { trochlear depth } \\
(1928,1012)\end{array}$ & 13 & $\begin{array}{l}\text { distance between the most anterior point and the most posterior } \\
\text { point on the trochlea }\end{array}$ \\
\hline $\begin{array}{l}\text { epiphysis thickness } \\
\text { at the proximal limit } \\
\text { of the olecranon } \\
\text { fossa }\end{array}$ & $\begin{array}{l}\text { (Leunda } \\
\text { 2016, 29) }\end{array}$ & $\begin{array}{l}\text { distance between the most anterior point to the most posterior } \\
\text { point of the epiphysis at the level of the proximal limit of the } \\
\text { olecranon fossa, perpendicular to the axis of the diaphysis }\end{array}$ \\
\hline $\begin{array}{l}\text { minimum trochlear } \\
\text { depth }\end{array}$ & $\begin{array}{l}\text { Trinkaus } \\
(1983,227)\end{array}$ & & \begin{tabular}{l} 
minimum anteroposterior dimension of the trochlea \\
\hline
\end{tabular}
\end{tabular}

Table 2. List of the six measurements taken on the distal humerus. 


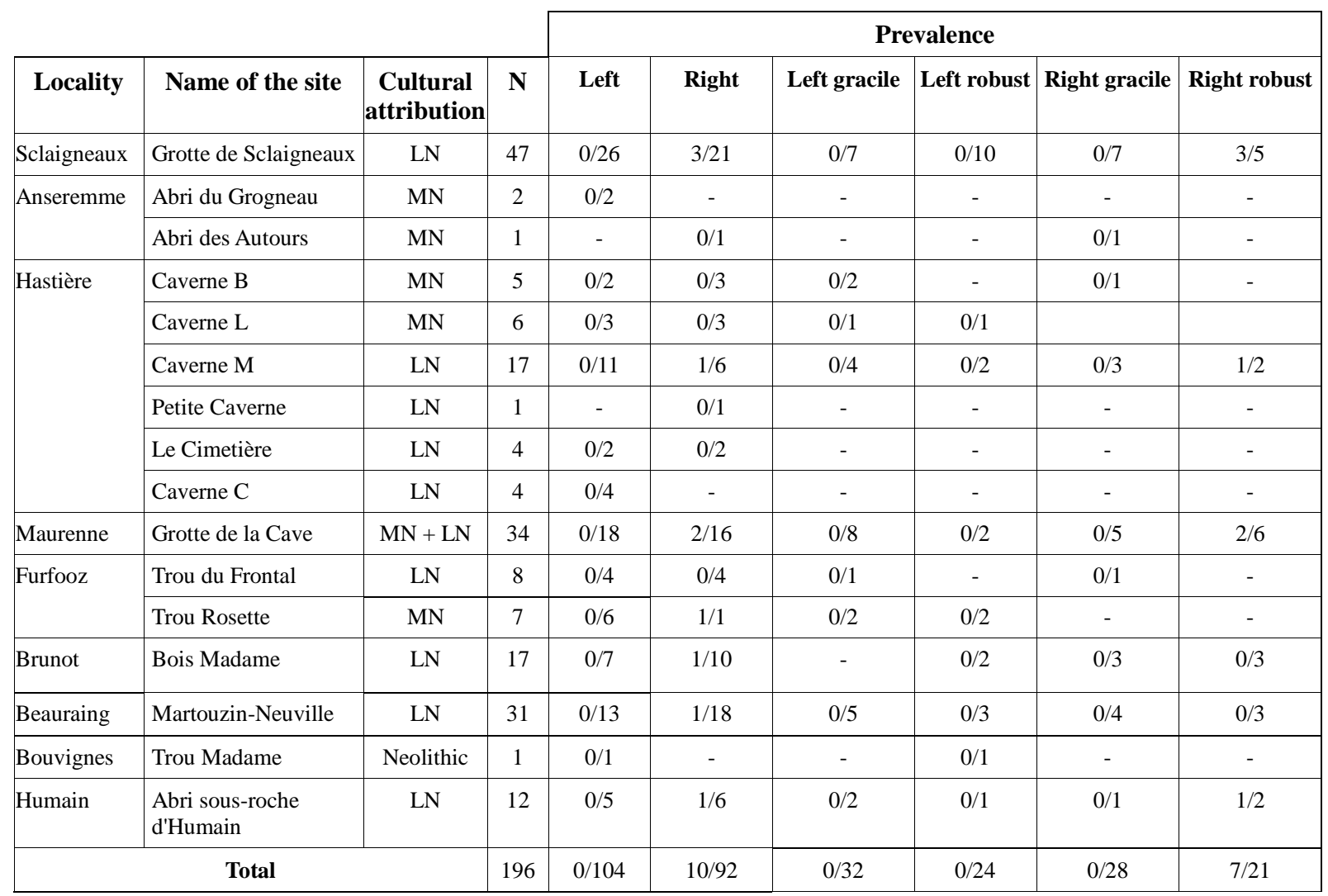

Table 3. Prevalence of medial collateral ligament (MCL) lesions in the Mosan human material. Locality, site name, excavation date, radiocarbon dating, cultural attribution, bibliographic references, minimum number of individuals (MNI), and the number of left and right humeri selected for this study. MN, Middle Neolithic; LN, Late Neolithic. 


\begin{tabular}{|l|l|l|l|l|}
\cline { 4 - 5 } \multicolumn{2}{c|}{} & \multicolumn{2}{c|}{ MCL lesion } \\
\hline humerus & $\mathrm{N}_{\text {tot }}$ & $\mathrm{N}_{\text {obs }}$ & Freq. (\%) \\
\hline right & gracile & 28 & 0 & 0 \\
\hline & robust & 21 & 7 & 33.33 \\
\hline left & gracile & 30 & 0 & 0 \\
\hline & robust & 24 & 0 & 0 \\
\hline
\end{tabular}

Table 4. Number and frequency of medial collateral ligament (MCL) lesions on the Neolithic humeri according to side and robusticity. 


\section{Figures}

Figure 1. Diagrammatic representation of the consequences of traction force exerted on the medial epicondyle (ME) of an adolescent humerus during throwing, which can lead to an avulsion fracture or epiphyseal detachment. When the individual with an avulsion fracture reaches adulthood, the healed lesion takes the form of a bony outgrowth or lacunae depending on whether or not the avulsed fragment re-united with the condyle.

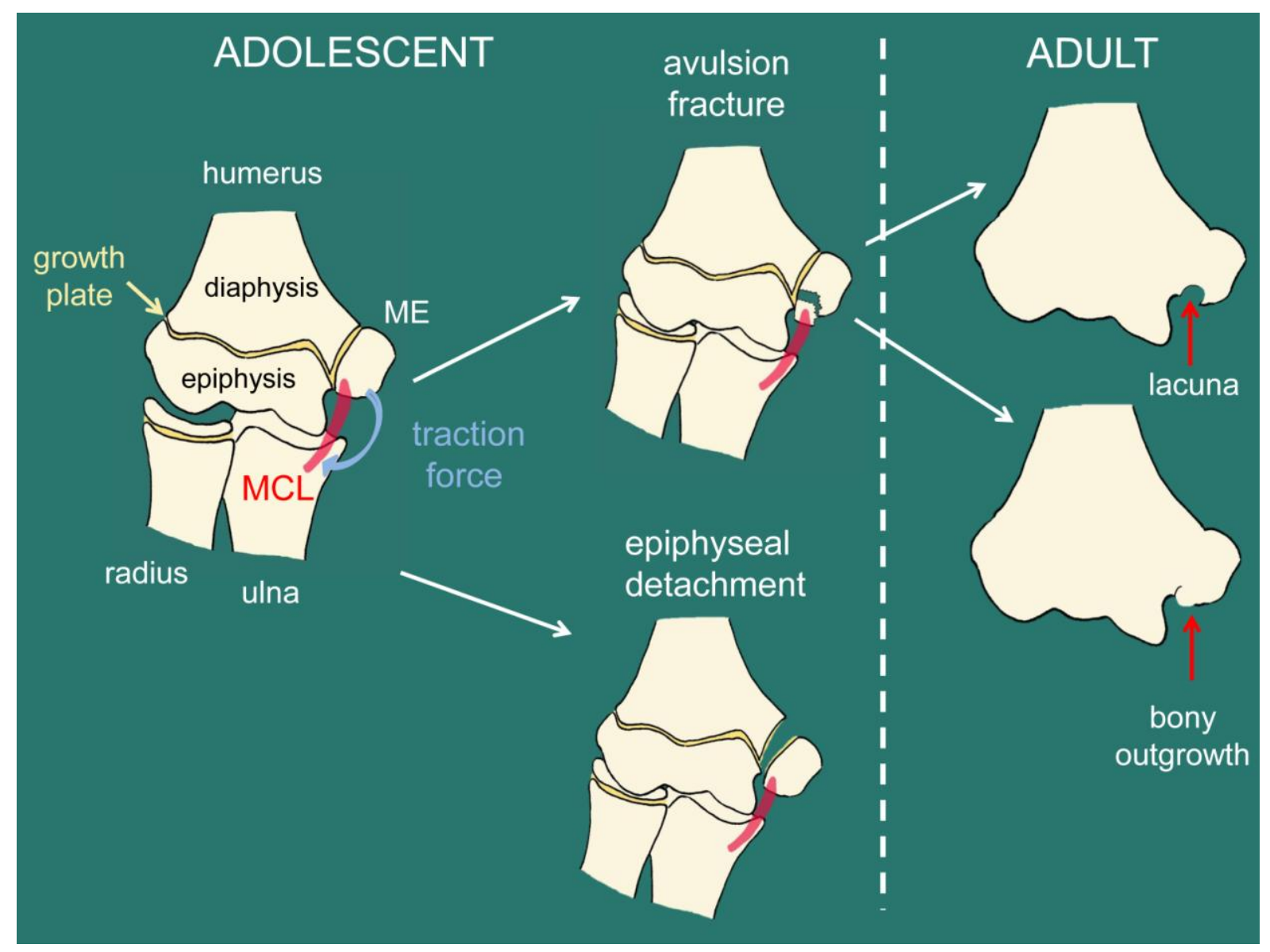


Figure 2. Map of Belgium with the locations of the studied sites. 1, Sclaigneaux; 2, Anseremme; 3, Hastière; 4, Maurenne; 5, Furfooz; 6, Burnot; 7, Beauraing; 8, Bouvignes-surmeuse; and 9, Humain.

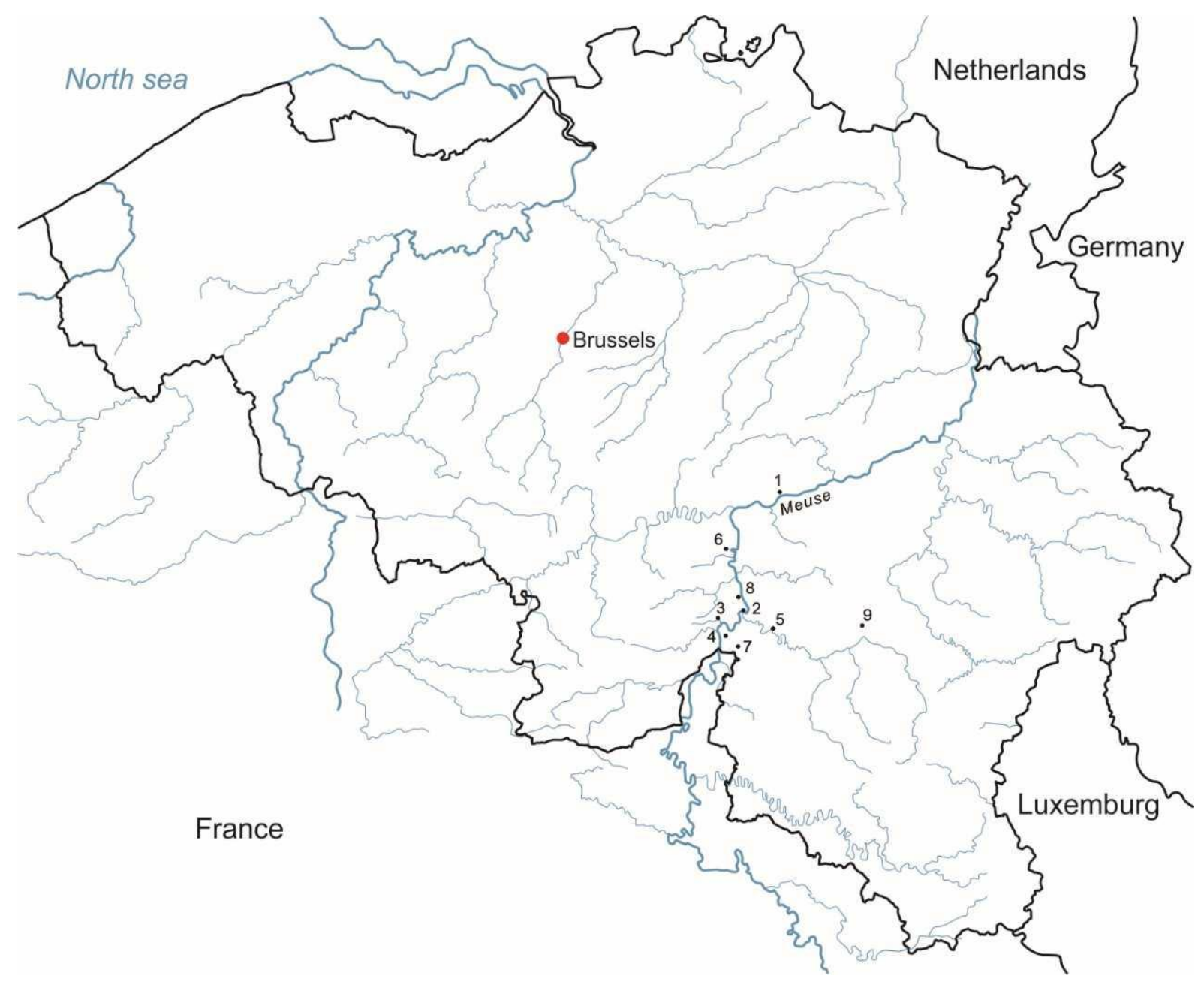


Figure 3. Example of a distinct bony protrusion from the enthesis surface resulting from an avulsion fracture in a right humerus that comes from an historical collection.

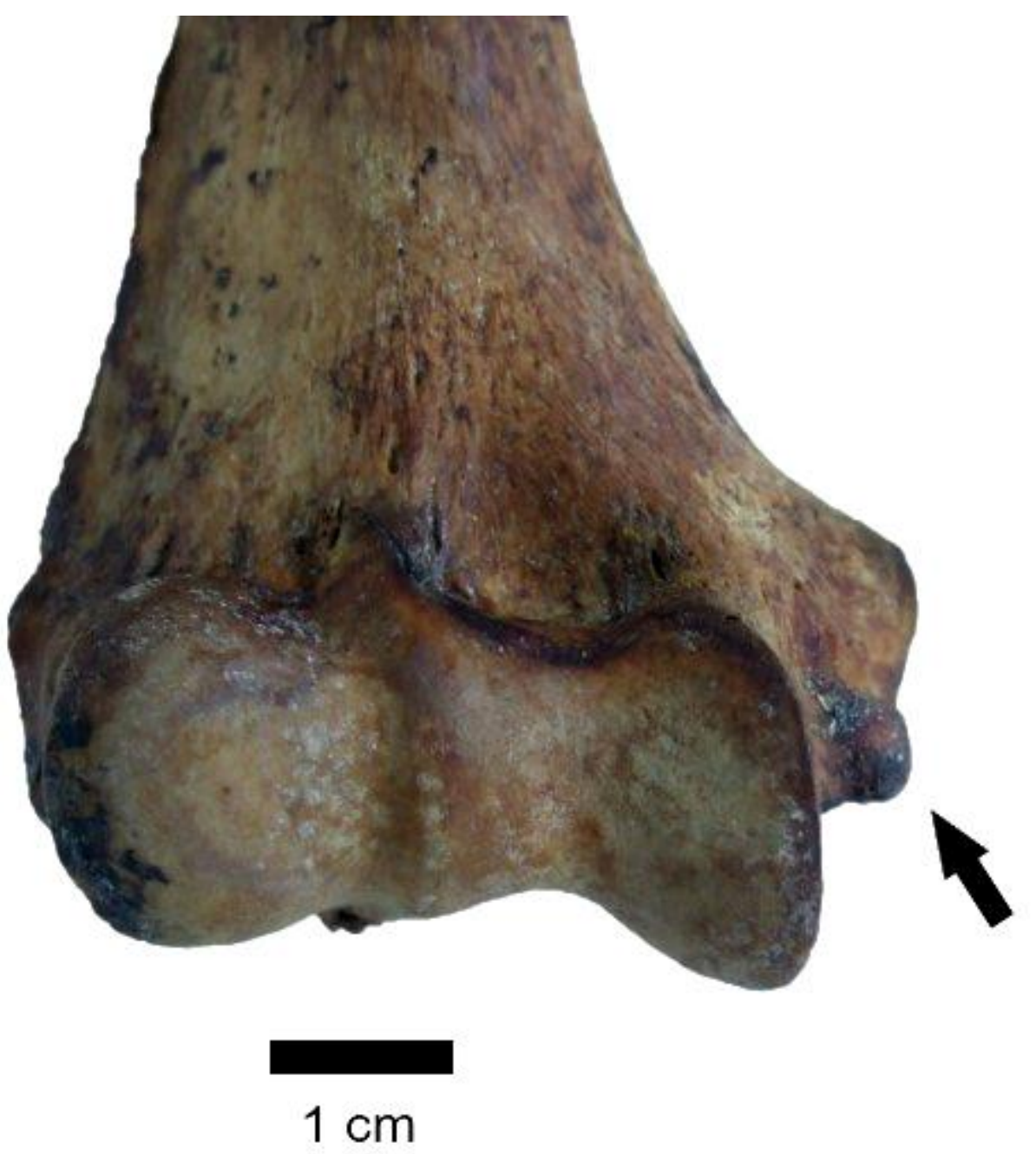


Figure 4. Example of bony defect resulting from an avulsion fracture in a right Neolithic humerus from the Meuse Basin.

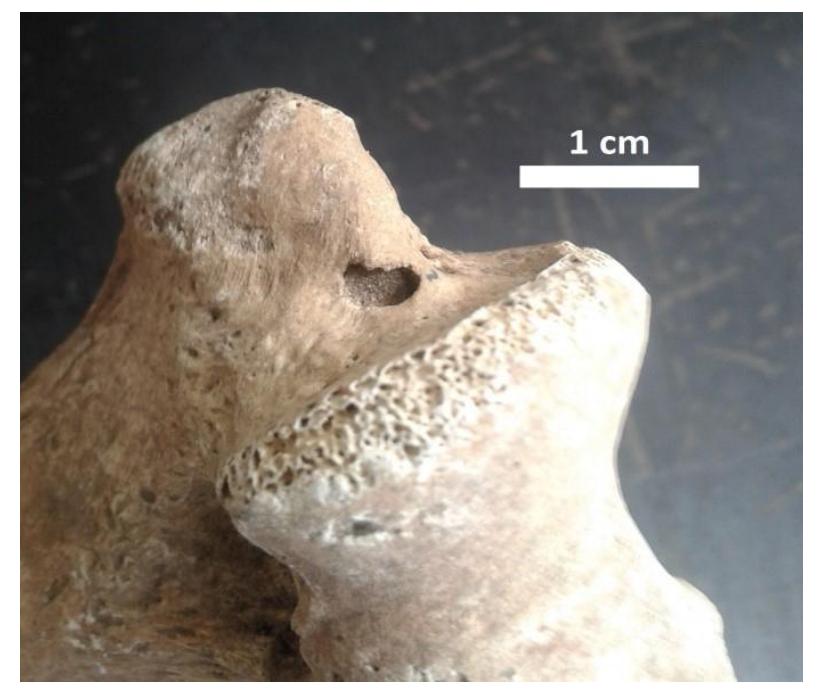


Figure 5. Measurements taken on the distal humerus. 1, epicondylar breadth; 2, distal articular breadth; 3, olecranon fossa breadth; 4, trochlear depth; 5, epiphysis thickness at the proximal limit of the olecranon fossa; 6 , minimum trochlear depth.
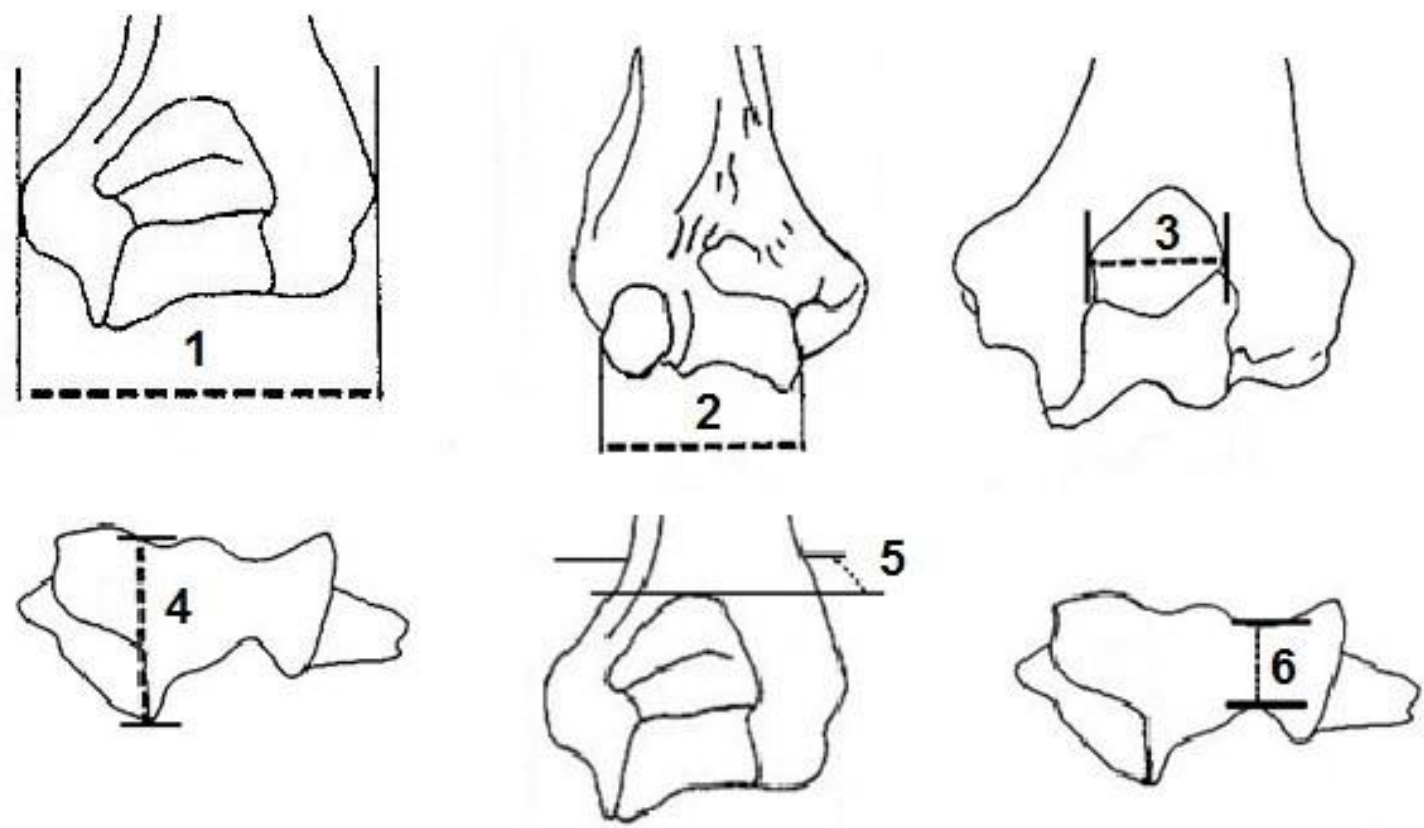
Figure 6. Bivariate plot with the epicondylar breadth and minimum trochlear depth for the Mosan humeri. The medians are represented by red dotted lines. The specimens with values below the median of both measurements were classified as gracile, and those above the median were considered robust.

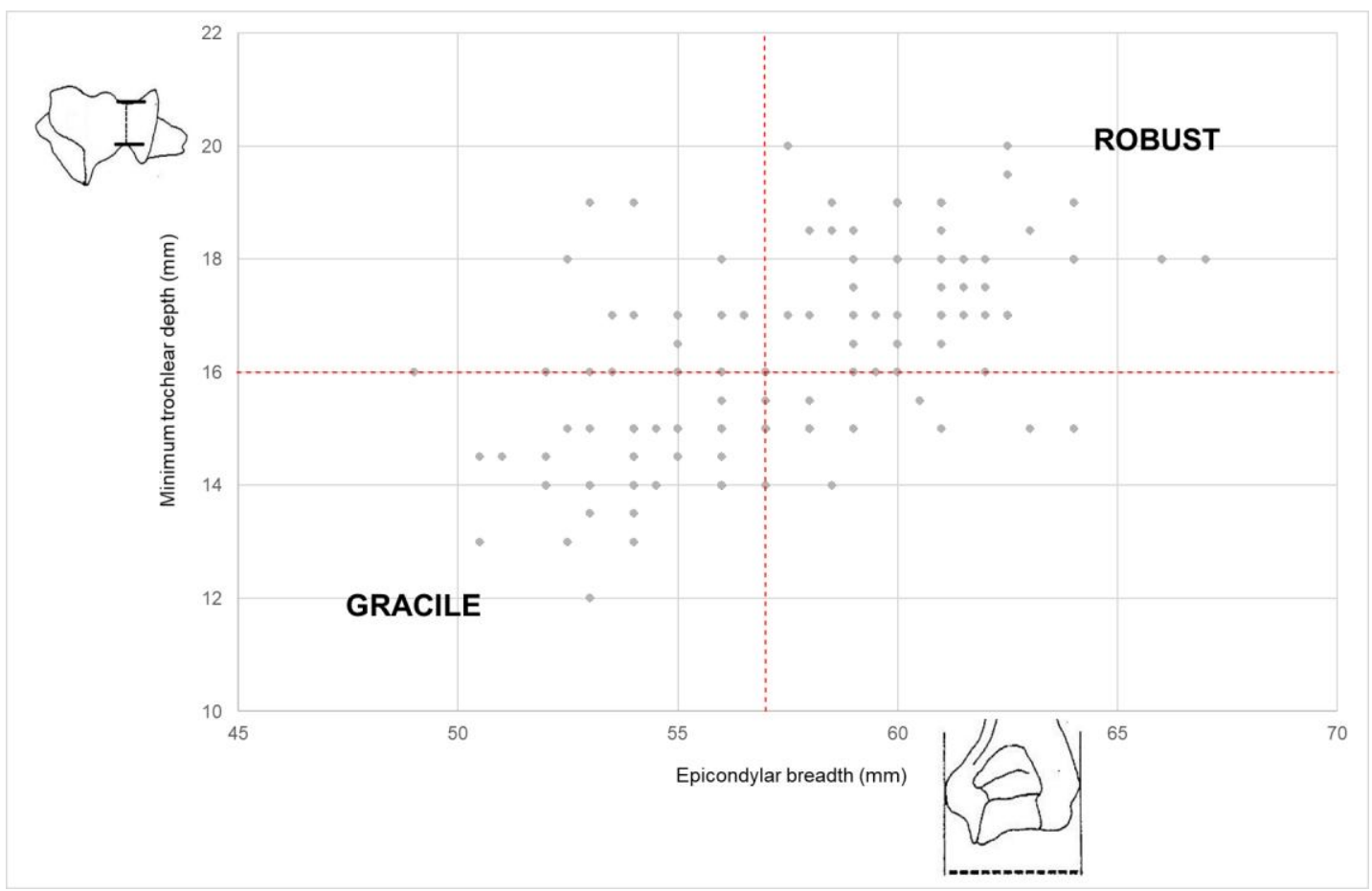

